\title{
Hygroscopic Property of Heat Treated Yellow Poplar (Liriodendron tulipifera) Wood $^{1}$
}

\author{
Yoon-Seong $\mathrm{CHANG}^{2}$ - Yeonjung $\mathrm{HAN}^{2}$ - Chang-Deuk $\mathrm{EOM}^{2}$ • \\ Sangjin $\mathrm{JEON}^{2} \cdot$ Hwanmyeong $\mathrm{YEO} \mathbb{D}^{3,4, \dagger}$
}

\begin{abstract}
In modern societies, people spend most of their time indoors and the temperature and humidity controlled by electrical appliances have a considerable effect on their emotions and health. However, improper operation of the artificial facilities frequently creates substances that are harmful to our body. The importance of controlling the natural humidity of interior materials has therefore attracted significant attention. This study was aimed at quantifying the hygroscopic property of some interior finishing wooden materials. Dried and heat-treated yellow poplar (Liriodendron tulipifera) lumbers, oriented strand board, and plywood were selected for this experiment. The moisture adsorption and desorption rates of wooden materials were measured (ISO 24353). Furthermore, the effects of morphological, physical and chemical factors, such as surface microstructure, roughness, and functional groups, on the hygroscopicity were evaluated. The results of this study should contribute to improved accuracy of hygroscopic-property assessments performed on wooden interior materials.
\end{abstract}

Keywords: hygroscopic property, wooden interior materials, adsorption, desorption, heat-treated wood

\section{INTRODUCTION}

In industrial societies, most people spend more than $90 \%$ of their lives inside buildings. The indoor relative humidity (RH), an important factor influencing indoor environments, is the primary cause of condensation and biological pollution such as mold (Sundell, 1996). Many studies have shown that hygroscopic materials can moderate the indoor RH conditions (Ten Wolde, 1994;
Plathner and Woloszyn, 2002; Simomson et al., 2002; 2004). Therefore, the importance of natural humidity in controlling the performance of interior materials has received considerable attention.

Wood is a hygroscopic material, owing to the $-\mathrm{OH}$ functional groups in the hydrophilic polymers such as celluloses and hemicelluloses, which form fixed water molecules by means of hydrogen bonds. This property allows the use of wood for interior finishing

${ }^{1}$ Date Received October 14, 2019, Date Accepted November 1, 2019

2 Department of Forest Products, National Institute of Forest Science, Seoul, 02455, Republic of Korea

${ }^{3}$ Department of Forest Sciences, College of Agriculture and Life Sciences, Seoul National University, Seoul 08826, Republic of Korea

${ }^{4}$ Research Institute of Agriculture and Life Sciences, Seoul National University, Seoul 08826, Republic of Korea

$\dagger$ Corresponding author: Hwanmyeong YEO (e-mail: hyeo@snu.ac.kr, ORCID: 0000-0002-1779-069X) 
or furnishing materials that moderate the indoor humidity of buildings. However, the hygroscopic performance of wood leads to undesirable properties, such as swelling and shrinkage caused by various indoor $\mathrm{RH}$ conditions, which limit the use of wood in various applications.

The hygroscopicity of wood can be modified via physical or chemical treatments. For example, this ability can be reduced through exposure of the wood to high temperatures, thereby leading to a decrease in the hemicellulose content (Nuopponen, 2005; Byeon et al., 2008; Kocaefe et al., 2008; Lee and Lee, 2018). Furthermore, heat treatment increases the dimensional stability of wood, and increases the applicability of low-strength material to interior finishing or furnishing material (Edvardsen and Sandland, 1999; Chung et al., 2016; Park et al., 2016).

The hygroscopic properties of wood are affected by morphological differences and the surface roughness. The anatomical structures resulting from the heat treatment process were examined by means of scanning electron microscopy (SEM) (Huang et al., 2012; Priadi and Hiziroglu, 2012). The correlation between the surface roughness values and the drying speed of wood was determined via correlation analysis. The results revealed that the surface roughness has no effect on the drying speed of the wood veneer in radial cut (Gungor et al., 2010). In this study, the hygroscopic property of some interior finishing or furnishing wooden materials was investigated. Moreover, the effects of heat treatment on the surface chemistry, morphology, and roughness were also evaluated.

\section{MATERIALS and METHODS}

\subsection{Materials}

Specimens for the sorption test were prepared from Yellow poplar (Liriodendron tulipifera) logs (25-30 year-old trees) obtained from Seoul National University forest, Gyungki-do, Korea. Sawn 50mm (thickness) $\times$ $150 \mathrm{~mm}$ (width) $\times 1,000 \mathrm{~mm}$ (length) lumber was prepared for air-drying (AD), kiln-drying (KD), and high-temperature heat treatment (HT).

In addition, $\mathrm{AD}$ from the green condition (average initial moisture content $68 \%$ ) was conducted for three months. Moreover, KD was carried out according to Forest Products Laboratory (FPL) drying schedule where an initial dry bulb temperature (DBT), initial $\mathrm{RH}$, final DBT, and final $\mathrm{RH}$ of $60^{\circ} \mathrm{C}, 87 \%, 82^{\circ} \mathrm{C}$, and $26 \%$, respectively, were employed. The HT experiments were performed for $6 \mathrm{~h}$ at a DBT of $200^{\circ} \mathrm{C}$.

To compare the hygroscopicity of the interior materials, Douglas-fir plywood and oriented strand board (OSB), which was commonly used for wooden wall materials, were employed.

\subsection{Ad/Desorption on/from wood}

Thirty pieces of yellow poplar (thickness $10 \mathrm{~mm}$, widths of $100 \mathrm{~mm} \times 100 \mathrm{~mm}$ and $150 \mathrm{~mm} \times 150 \mathrm{~mm})$ for $\mathrm{AD}, \mathrm{KD}$, and $\mathrm{HT}$ were prepared for the experiment. Furthermore, 10 pieces of each OSB and plywood also were prepared with same size. Except for the surface areas (radial section) to be measured, all the sections were sealed by aluminum tape. Using a temperature and humidity chamber, the mass of wood at each equilibrium condition was measured during $24 \mathrm{~h}$ until the mass change was less than $0.01 \mathrm{~g}$. Afterward, to raise the $\mathrm{RH}$, the adsorption process was performed for $12 \mathrm{~h}$ and the mass of the specimen was measured. The $\mathrm{RH}$ was then reduced and the desorption process was performed for $12 \mathrm{~h}$. Subsequently, the mass of the specimen was measured (Table 1).

The moisture ad/desorption content and rates of moisture ad/desorption after $12 \mathrm{~h}$ at each state were calculated as follows: 
Table 1. Humidity conditions for testing specimens

\begin{tabular}{ccc}
\hline $\begin{array}{c}\text { Humidity Conditions } \\
\left.\text { (Temp. } 23^{\circ} \mathrm{C}\right)\end{array}$ & \multicolumn{2}{c}{ Relative Humidity (\%) } \\
\cline { 2 - 3 } & Adsorption $(12 \mathrm{~h})$ & Desorption $(12 \mathrm{~h})$ \\
\hline \hline Low (Equilibrated at $30 \% \mathrm{RH})$ & 55 & 50 \\
Medium (Equilibrated at $50 \% \mathrm{RH})$ & 75 & 70 \\
High (Equilibrated at $70 \% \mathrm{RH})$ & 95 & 50 \\
\hline
\end{tabular}

$$
\begin{aligned}
& \rho_{\mathrm{a}}=\frac{\mathrm{w}_{\mathrm{a}}-\mathrm{w}_{0}}{\mathrm{~A}} \\
& \rho_{\mathrm{d}}=\frac{\mathrm{w}_{\mathrm{a}}-\mathrm{w}_{\mathrm{d}}}{\mathrm{A}} \\
& \mathrm{G}_{\mathrm{n}}=\frac{\mathrm{w}_{\mathrm{n}}-\mathrm{w}_{\mathrm{n}-1}}{\mathrm{~A} \cdot \Delta \mathrm{t}}
\end{aligned}
$$

$\rho_{\mathrm{a}}=$ Moisture adsorption content $\left(\mathrm{kg} / \mathrm{m}^{2}\right)$

$\rho_{\mathrm{d}}=$ Moisture desorption content $\left(\mathrm{kg} / \mathrm{m}^{2}\right)$

$\mathrm{G}_{\mathrm{n}}=$ Moisture sorption rate at $\mathrm{n}_{\mathrm{th}}$ state $\left(\mathrm{kg} /\left(\mathrm{m}^{2} \cdot \mathrm{h}\right)\right)$

$\mathrm{w}_{\mathrm{o}}=$ Weight of final state at equilibrium $(\mathrm{kg})$

$\mathrm{W}_{\mathrm{a}}=$ Weight of final state at adsorption $(\mathrm{kg}$, after $12 \mathrm{~h})$

$\mathrm{W}_{\mathrm{d}}=$ Weight of final state at desorption ( $\mathrm{kg}$, after $12 \mathrm{~h}$ )

$\mathrm{w}_{\mathrm{n}}=$ Weight at $\mathrm{n}_{\mathrm{th}}$ state $(\mathrm{kg}$, after $12 \mathrm{~h})$

$\mathrm{W}_{\mathrm{n}-1}=$ Weight at $\mathrm{n}-1_{\text {th }}$ state $(\mathrm{kg}$, after $12 \mathrm{~h})$

A $=$ Surface area $\left(\mathrm{m}^{2}\right)$

$\mathrm{t}=$ Time $(\mathrm{h})$

\subsection{Functional groups}

Heat-treatment-induced changes in the functional groups of the wood were evaluated via FT-IR spectrum analysis of the wood. The specimens were prepared for FT-IR via ball milling (Pulverisette 23, Fritsch) using a 100 mesh. The corresponding spectra were recorded (resolution: $8 \mathrm{~cm}^{-1}$ ) on a FT-IR-6100 (Jasco, Japan) spectrometer, operating over a spectral range of 650 $4000 \mathrm{~cm}^{-1}$.

\subsection{Microstructural characterization}

The microstructures of the untreated and heat-treated wood were characterized by means of field-emission scanning electron microscopy (FE-SEM; SUPRA 55VP,
Carl Zeiss, Germany). A microtome was used to prepare $10 \mathrm{~mm} \times 10 \mathrm{~mm}$ (widths) cross-sections (thickness: $100 \mu \mathrm{m})$ of the untreated and heat-treated wood.

\subsection{Surface roughness}

Surface roughness analysis was performed, in accordance with ISO 4287 (1998), using spiny sweeping equipment (TR-200, Time High Tech.). The measurements were conducted at ten different points on each sample, along the vertical direction of the grains. The measurements were performed at a temperature of $20^{\circ} \mathrm{C}$ and a RH of $50 \%$. The device, which was adjusted to $0.25-\mathrm{mm}$ measurement steps and five measurement numbers (cut-off), was located between two lines with a rift of $5 \mathrm{~mm}$. The surface roughness was measured by constructing a profile of the valleys and ridges on the surface by moving the sweeping needle (with a 5 - $\mu$ m-diameter diamond tip) across the surface of the sample (Budakçı et al., 2001). The surface section of the HT wood was ground by 180 -grit and 1000 -grit sandpaper and the adsorption rate of this section was then measured (temperature: $20^{\circ} \mathrm{C}$, RH: $50 \%$ ).

\section{RESULTS and DISCUSSION}

\subsection{Ad/desorption on/from wood}

Fig. 1 shows the calculated moisture ad/desorption content associated with $12 \mathrm{~h}$ under each condition. In the case of relative humidity, the highest moisture ad/desorption content was obtained under high humidity 


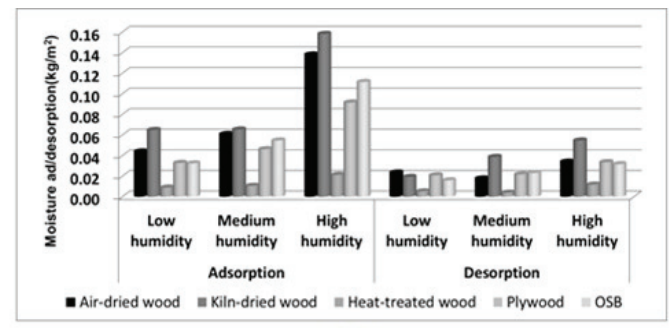

(a)

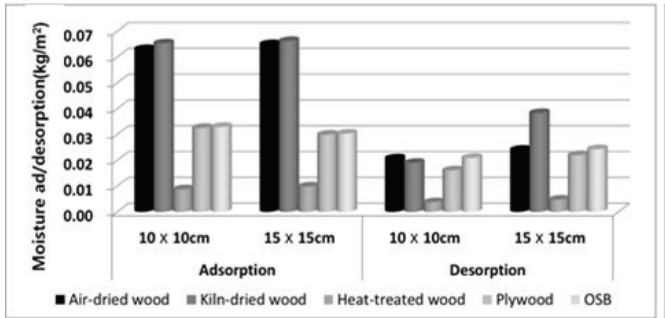

(b)

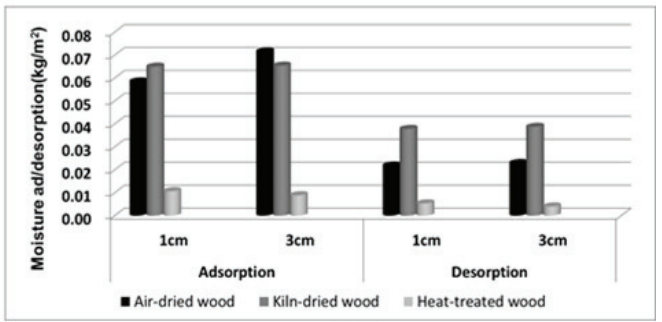

(c)

Fig. 1. Moisture content of wood after 12-h adsorption and desorption under different conditions ((a) Relative humidity, (b) surface area, and (c) thickness).

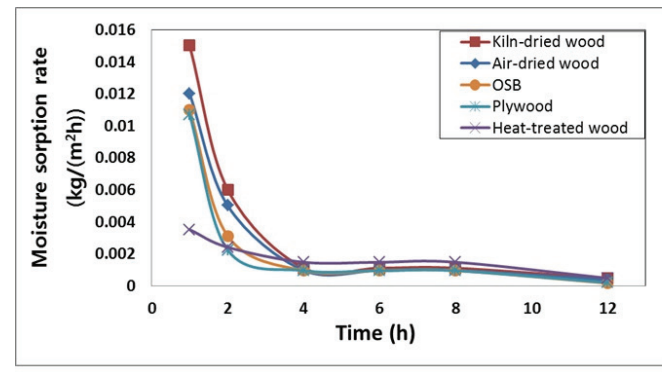

(a)

Fig. 2. Moisture adsorption (a) and desorption Liriodendron tulipifera wood.

conditions. This may be attributed to the sorption property of bound water on wood where capillary condensed water occurs under high relative humidity conditions. Similar moisture ad/desorption levels were observed for different surface area and thickness values.

Due to insufficient time for equilibration of the moisture content between the surface layer and core layer of the specimen, the water molecule adsorbed in the surface layer moved rapidly to the core layer. Therefore, this adsorption is slightly affected by the

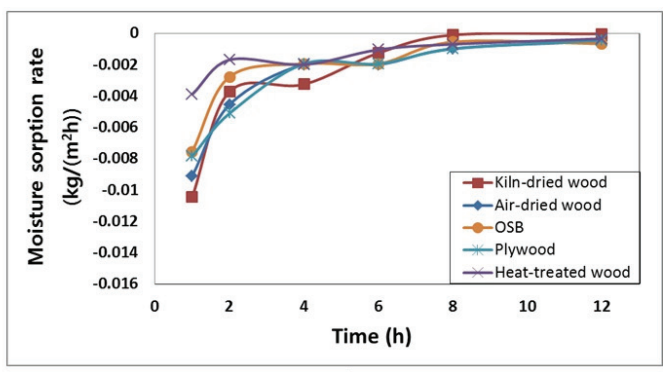

(b)

surface area and thickness in finite time $(24 \mathrm{~h})$. These results corresponded to changing humidity conditions in the building during the day. The data is required for calculating the appropriate area and thickness of the wooden interior materials associated with a given size of space and changing humidity conditions in a building. These data were calculated based on 12-h cycles, but hourly measurements were required for determining the moisture ad/desorption rates. As Fig. 2 shows, the ad/desorption rate of each material was 
high initially, decreased sharply within $2 \mathrm{~h}$, and then converged within $12 \mathrm{~h}$.

The rates of moisture ad/desorption indicate the degree of moisture ad/desorption of materials per unit surface area and time, and high values are indicative of an efficient response to rapid changes in humidity. The ad/desorption rates of the HT wood specimens were lower than those of the other wood specimens. This resulted from the hydrophobicity of the wood surface that renders adsorption of water molecules difficult. Moreover, the rates of moisture ad/desorption on the $\mathrm{KD}$ wood were higher than that of the $\mathrm{AD}$ wood. Vapor and moisture transfer on the former were easier than that of the latter because the number of pores in the wood increased with volatilization of wood extractives during KD wood. Plywood and OSB exhibited similar moisture ad/desorption rates, and the rapid gradient observed indicated that those approached the equilibrium state more rapidly than the rates of other materials $(2 \mathrm{~h})$. That is, compared with that of the other hygroscopic materials, the hydrophobicity of the wooden resin render the adsorption of water molecules difficult.

\subsection{Functional groups}

Fig. 3 shows FT-IR spectra obtained for the $\mathrm{AD} /$ $\mathrm{KD} / \mathrm{HT}$ yellow poplar wood. The moisture adsorption point of the wood corresponded to the $\mathrm{OH}$ group from cellulose and hemicellulose, and was related to the hygroscopic property of the wood. For the wood subjected to the high-temperature treatment, the peaks occurring at $3400 \mathrm{~cm}^{-1}$ and $2900 \mathrm{~cm}^{-1}$ represent the $\mathrm{OH}$ group and the $\mathrm{C}-\mathrm{H}$ group associated with symmetric stretching in aliphatic methyl, respectively. This indicates that combinations of the alkyl group, aromatic compound, and carboxylic acid were broken, owing to the dehydration resulting from the heat treatment.

The band occurring at $1510 \mathrm{~cm}^{-1}$ is characteristic of the $\mathrm{C}=\mathrm{C}$ stretching vibration in the aromatic skeletal of lignin. The heat treatment led to a reduction in the absorbance associated with this characteristic band of lignin (Nuopponen et al., 2003). In the KD wood, the peaks at $3400 \mathrm{~cm}^{-1}$ resulted from water-molecule loss and combination between the cellulose. This combination and loss occurred simultaneously with the formation of ester linkages during the heat treatment, thereby reducing the ratio of hemicellulose, which

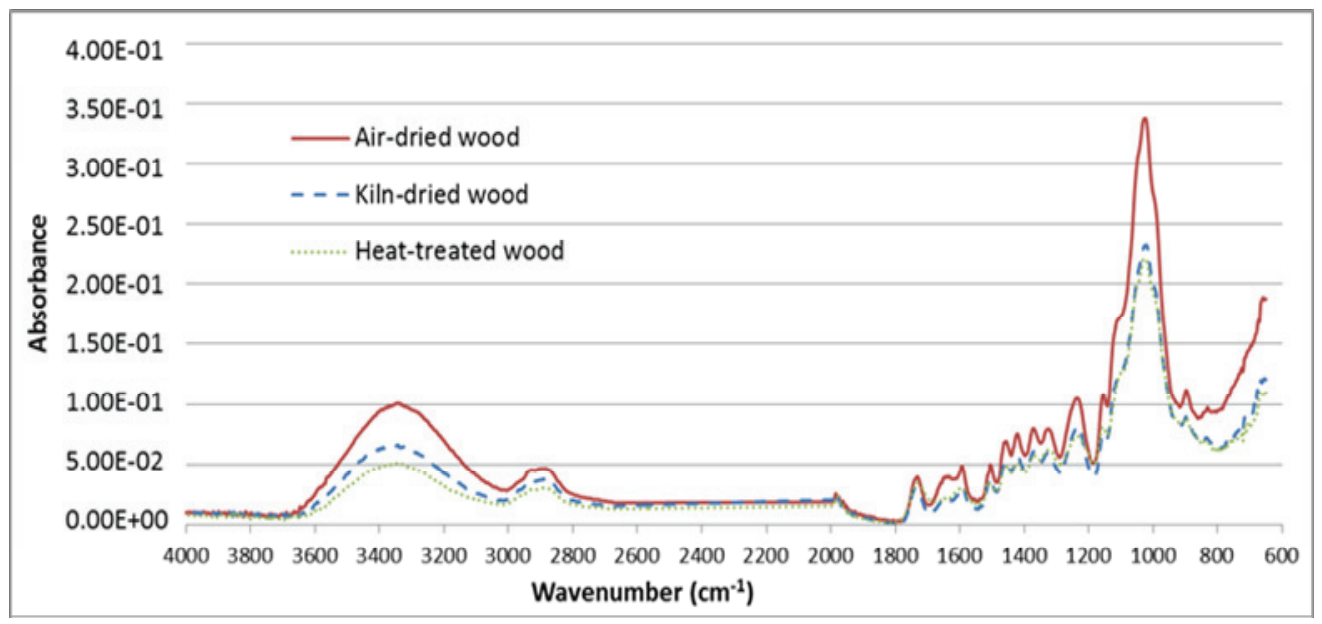

Fig. 3. FT-IR spectrum of air-dried, kiln-dried, and heat-treated Liriodendron tulipifera wood. 


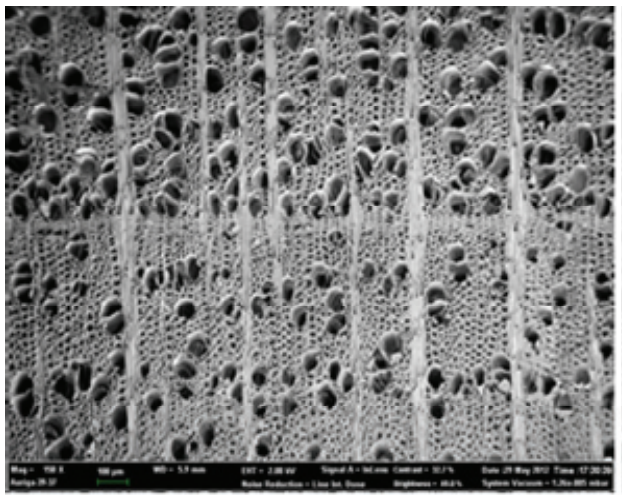

(a)

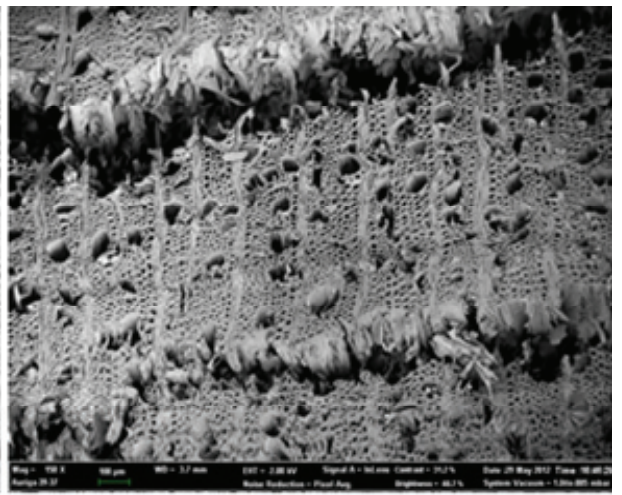

(b)

Fig. 4. Cross-sectional SEM images of air-dried (a) and heat-treated wood (b).

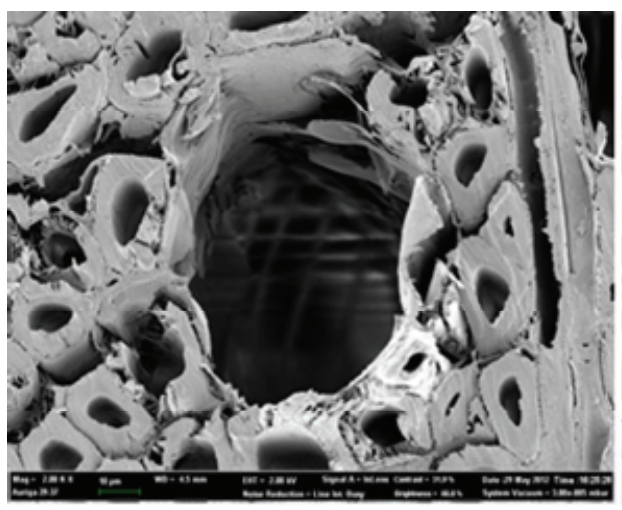

(a)

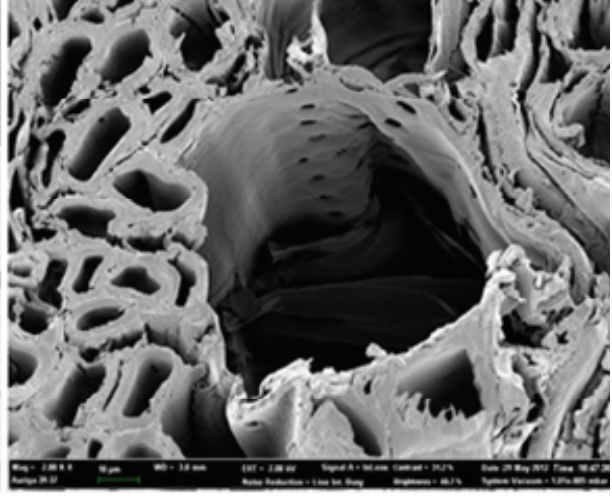

(b)

Fig. 5. SEM images on cell walls of the air-dried wood (a) and heat-treated wood (b).

have many $\mathrm{OH}$ groups. However, the moisture ad/ desorption rates of the KD wood werehigher than those of the AD wood. Similarly, vapor and moisture transfer were easier because the number of micro-pores formed on the wood cell wall of the KD wood increased with drying-induced volatilization of the wood extractives.

\subsection{Microstructural characterization}

The microstructural changes induced by heat treatment of the wood were evaluated via SEM. As Fig. 4 shows, the HT wood is characterized by many micro-cracks, shrinkage of the cell wall, and collapsed wood cells resulting from considerable water loss from the wood.

Mburu et al. reported that the differences resulted from the presence of extractives deposited in the resin channels, which evaporated after heat treatment (Mburu et al., 2007). Fig. 5 reveals the presence of small cracks on the middle lamella and a significant decrease in the cell wall width. The expansion of the micromovement path resulted in a decrease in the vapor diffusion resistance and, consequently, an increase in the speed of ad/desorption. However, the effects of structural changes by heat treatment were less severe than those of chemical changes such as hydrophobicity 
Table 2. Surface roughness values of specimens abraded with 180-grit and 1000-grit sandpaper

\begin{tabular}{ccccc}
\hline \multirow{2}{*}{ Material } & \multicolumn{5}{c}{ Roughness $(\mu \mathrm{m})$} \\
\cline { 2 - 5 } & $\mathrm{R}_{\mathrm{a}}$ & $\mathrm{R}_{\mathrm{q}}$ & $\mathrm{R}_{\mathrm{t}}$ & $\mathrm{R}_{\mathrm{z}}$ \\
\hline \hline 180 grit & 8.09 & 11.83 & 45.85 & 31.95 \\
1000 grit & 3.60 & 5.37 & 41.10 & 28.20 \\
\hline
\end{tabular}

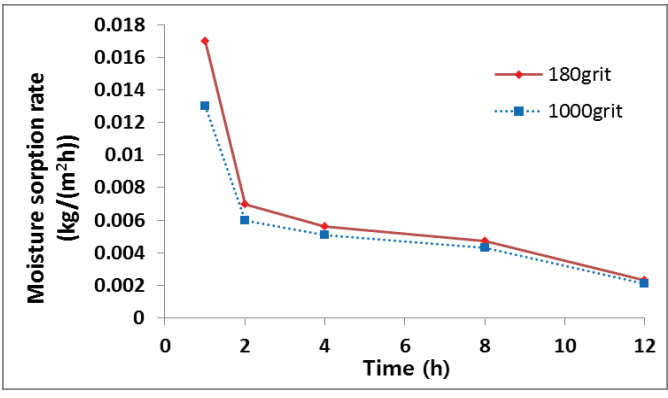

Fig. 6. Moisture adsorption rate associated with surface roughness of wood.

and moisture ad/desorption (Awoymi and Jones 2011).

\subsection{Roughness}

To elucidate the effect of heat treatment on hydrophobicity, the adsorption rate of HT wood was measured for samples prepared using 180-grit and 1000-grit sandpaper. The effect of heat treatment on the surface roughness of the wood was evaluated by considering four main roughness parameters which mean arithmetic deviation of the profile $\left(\mathrm{R}_{\mathrm{a}}\right)$, root mean square roughness $\left(R_{q}\right)$, maximum roughness $\left(R_{t}\right)$, and mean peak-to-valley height $\left(\mathrm{R}_{\mathrm{z}}\right)$.

For the HT wood ground by sandpaper, $\mathrm{R}_{\mathrm{a}}: 8 \mu \mathrm{m}$, $\mathrm{R}_{\mathrm{q}}: 12 \mu \mathrm{m}$ at 180 -grit and $\mathrm{R}_{\mathrm{a}}: 4 \mu \mathrm{m}, \mathrm{R}_{\mathrm{q}}: 5 \mu \mathrm{m}$ at 1000 -grit (Table 2).

The moisture adsorption rate associated with the 180-grit sandpaper is higher than that of the 1000-grit paper, owing possibly to the fact that the high roughness increased the contact surface between the water molecules and the wood surface. The difference of initial rate of adsorption was $5 \mathrm{~g} / \mathrm{m}^{2} \mathrm{~h}$ in both cases, and the difference between the rates decreased gradually (Fig 6). The surface roughness played a major role in the initial stage of adsorption, because water molecules were adsorbed on the surface of the wood. However, this role decreased due to gradual diffusion of water molecules into the wood cell wall.

\section{CONCLUSION}

This study was aimed at changing the hygroscopic property of yellow poplar by means of heat treatment. The moisture ad/desorption content of the KD wood was higher than that of the $\mathrm{AD}$ wood. These results were attributed to changes in the microstructure, surface roughness, and functional groups. The roughness was considered a major factor in the initial ad/desorption. Moreover, the highest rate of ad/desorption was observed for the KD wood indicating the satisfactory hygroscopic performance of this wood, even with significant changes in the humidity condition. Heat treatment performed at appropriate temperatures will contribute to changed hygroscopic performance of wood. Although the hygroscopic property of the HT wood was inferior to that of the $\mathrm{KD}$ wood, this wood exhibited high dimensional stability and decay resistance for use in wooden products.

Therefore, this type of wood is used as interior material in spaces under continuous high RH conditions. In addition, a substance exhibiting outstanding hygroscopic property may have been injected into the extended numerous pores of the HT wood to change the hygroscopic performance. The results of this study 
provide basic data for quantifying the hygroscopic property of residential spaces on wooden houses.

\section{REFERENCES}

Awoyemi, L., Jones, I.P. 2011. Anatomical explanations for the changes in properties of western red cedar (Thuja plicata) wood during heat treatment. Wood Science Technology 45(2): 261-267.

Budakçı, M., Ilçe, A.C., Korkut, D.S., Gurleyen, T. 2001. Evaluating the surface roughness of heattreated wood cut with different circular saws. BioResources 6(4): 4247-4258.

Byeon, H.S., Lee, W.H., Park, B.S., Jeong, S.H., Kang, H.Y. 2008. Study on physical properties of domestic species II: Sorption, thermal, electrical and acoustic properties of Pinus Koraiensis and Larix Kaempferi. Journal of the Korean Wood Science and Technology 36(4): 1-10.

Chung, H., Han, Y., Park, J.H., Chang, Y.S., Park, Y., Yang, S.Y., Yeo, H. 2016. A study on dimensional stability and thermal performance of superheated steam treated and thermal compressed wood. Journal of the Korean Wood Science and Technology 44(2): 184-190.

Edvardsen, K., Sandland, K.M. 1999. Increased drying temperature - Its influence on the dimensional stability of wood. Holz als Roh- und Werkstoff 57(3): 207-209.

Gungor, N.M., Kantay, R., Korkut, S. 2010. Effect of surface roughness on drying speed of drying lamellas in veneer roller dryer. African Journal of Biotechnology 9(25): 3840-3846.

Huang, X., Kocaefe, D., Kocaefe, Y., Boluk, Y., Pichette, A. 2012. Changes in wettability of heat-treated wood due to artificial weathering. Wood Science Technology 46(6): 1215-1237.

ISO 4287. 1998. Geometrical Product Specifications (GPS), Surface Texture, Profile Method, Terms,
Definitions and Surface Texture Parameters. ISO, Geneva, Switzerland.

Kang, C.W., Kim, N.H., Kim, B., Kim, Y.S., Byeon, H.S., So, W.T., Yeo, H., Oh, S.W., Lee, W.H., Lee, H.Y. 2008. Wood Physics \& Mechanics. Hyangmoonsa. pp. 338.

Kocaefe, D., Poncsak, S., Boluk, Y. 2008. Effect of thermal treatment on the chemical composition and mechanical properties of birch and aspen. Bioresources 3(2): 517-537.

Lee, J.M., Lee, W.H. 2018. Dimensional stabilization through heat treatment of thermally compressed wood of Korean pine. Journal of the Korean Wood Science and Technology 46(5): 471-485.

Mburu, F., Dumarçay, S., Huber, F., Petrissans, M., Gérardin, P. 2007. Evaluation of thermally modified Grevillea robusta heartwood as an alternative to shortage of wood resource in Kenya: Characterisation of physicochemical properties and improvement of bio-resistance. Bioresource Technology 98(18): 3478-3486.

Nuopponen, M., Vuorinen, T., Jämsä, S., Viitaniemi, P. 2003. The effects of heat treatment on the behavior of extractives in softwood studied by FTIR spectroscopic methods. Wood Science Technology 37(2): 109-115.

Nuopponen, M. 2005. FT-IR and UV Raman spectroscopic studies on thermal modification of scots pine wood and its extractable compounds. Ph.D. Thesis,

Park, Y., Park, J.H., Yang, S.Y., Chung, H., Kim, H., Han, Y., Chang, Y.S., Kim, K., Yeo, H. 2016. Evaluation of physico-mechanical properties and durability of Larix kaempferi wood heat-treated by superheated steam. Journal of the Korean Wood Science and Technology 44(5): 776-784.

Plathner, P., Woloszyn, M. 2002. Interzonal air and moisture transport in a test house: experiment and modelling. Building and Environment 37(2): 189-199. 
Priadi, T., Hiziroglu., S. 2012. Characterization of heat treated wood species. Materials \& Design 49(8): 575-582.

Simonson, C.J., Salonvaara, M., Ojanen, T. 2002. The effect of structures on indoor humidity - Possibility to improve comfort and perceived air quality. Indoor Air 12(4): 243-251.

Simonson, C.J., Salonvaara, M., Ojanen, T. 2004. Moderating indoor conditions with hygroscopic building materials and outdoor ventilation. ASHRAE Transactions 110(2): 804-819. Atlanta: American Society of Heating, Refrigerating and Air-Conditioning Engineers, Inc.
Straže, A., Pervan, S., Gorišek, Ž. 2010. Impact of various conventional drying conditions on drying rate and on moisture content gradient during early stage of beechwood drying. Proceeding of Conference COST Action E53 "The Future of Quality Control for Wood \& Wood Products.” NO.56 paper.

Sundell, J. 1996. What we know and don't know about sick building syndrome. ASHRAE Journal 38(6): 51-57.

Ten Wolde, A. 1994. Ventilation, humidity, and condensation in manufactured houses during winter. ASHRAE Transactions 100(1): 103-115. 